\title{
Xi Jinping's Contemporary Value of Strictly Administering the Party's Thought
}

\author{
Wang Siqi \\ China JiLiang University \\ Hangzhou, Zhejiang Province, 310018
}

\begin{abstract}
The Party's strict administration in an all-round way has rich thought and connotation: taking the party constitution as the highest standard, strictly administering the party with the strictest discipline and the most serious attitude, covering the content, cycle, and subject, the party members and cadres assuming corresponding responsibilities and receiving strict management, unswervingly punishing corruption, adhering to the spiritual pursuit of the Communists, doing a good job in ideological education, maintaining the flesh-and-blood ties between the party and the people, and strictly observing the party discipline. The thought of ruling the Party strictly in an allround way has further enriched and developed the Marxist theory of Party building, raised the scientific level of Party building, and has great and far-reaching significance for realizing the goal of "Two Centenary Goals" and the great rejuvenation of the Chinese nation.
\end{abstract}

Keywords-Xi Jinping; Comprehensively administering the party strictly; Party building; China dream

\section{INTRODUCTION}

Strictly administering the party and maintaining the party's advanced nature is a basic principle for our party to strengthen its own construction. The report of the 18th National Congress of the Communist Party of China pointed out: Under the new situation, leading the people of the whole country to realize the great rejuvenation of the Chinese nation is an important task that our party must shoulder. Nowadays, our party has "four major dangers": mental slackness, lack of ability, separation from the masses, and risk of negative corruption. It also faces the "four major tests", namely, governance, reform and opening up, market economy, and external environment. We need to improve the party's leadership and governance, and improve anti-corruption and anti-risk capabilities. All of this requires us to strictly manage the party and improve the scientific level of party building.

\section{XI JINPING'S PROPOSAL AND DEVELOPMENT OF STRICTLY ADMINISTERING THE PARTY'S THOUGHT}

General Secretary Xi Jinping pointed out at the 2013 National Organization Work Conference: If the party is not strictly governed, then our party will lose its ability to govern. Since the reform and opening up, the Party Central with General Secretary Xi Jinping as the core has incorporated the comprehensive and strict governance of the party into the general layout of governing the country. In December 2014,

"Xi Jinping's Talk on Governing the Country" (Volume II) [M]. Beijing: Foreign Languages Press, 2017.
General Secretary Xi Jinping said during the investigation and study in Jiangsu: "We must fully implement the spirit of the Party's 18th and the Third and Fourth Plenary Sessions of Party's 18th, implement the spirit of the Central Economic Work Conference, and actively grasp and actively adapt to the new normal state of economic development. Coordinate and promote the comprehensive construction of a well-off society, comprehensively deepen reforms, comprehensively promote the rule of law, comprehensively and strictly manage the party, and push reform, opening up, and socialist modernization to a new level."[1] This marks the formation of the "four comprehensive" strategic layout, which marks the comprehensive and strict governance of the party into the strategic layout of party governance. On January 12, 2016, General Secretary Xi Jinping re-emphasized the importance of comprehensively administering the party strictly at the Sixth Plenary Session of the 18th Central Commission for Discipline Inspection. He pointed out that the rule of the country must be governed first and the party must be strict.

On October 18, 2017, General Secretary Xi Jinping pointed out in the report of the 19th National Congress of the Communist Party of China that "adhering to the strict management of the party, the courage to self-revolution, and the strict management of the party, is the most distinctive character of our party."[2] Strictly administering the party is a major issue of the party's construction. It is an important part of $\mathrm{Xi}$ Jinping's socialist ideology with Chinese characteristics in the new era. It is the basic strategy for adhering to and developing socialism with Chinese characteristics in the new era. It must run through the entire process of socialist construction with Chinese characteristics.

From the party's management of the party and the strict administration of the party to the comprehensive and strict management of the party, it is an inevitable trend of upholding the party's management of the party and strictly administering the party's historical experience. It is in keeping with the inherent requirements of the party's nature, purpose and ruling mission, an important guarantee for promoting the modernization process of state governance, and an objective need for solving outstanding problems within the Party. [3]To realize the great rejuvenation of the Chinese nation, we must adhere to the path of socialism with Chinese characteristics, adhere to the theoretical system of socialism with Chinese characteristics, must carry forward the national spirit with patriotism as the core, and must unite the strength of the 
Chinese people, To achieve this, we need to strengthen the party's leadership, adhere to the strict and strict management of the party, and maintain the party's advanced nature and purity. Strictly administering the party strictly is the fundamental guarantee for realizing the Chinese dream. [4]Upholding the leadership of the party is the choice of the Chinese people. To realize the Chinese dream, we must conform to the wishes of the people, strictly manage the party, closely link the flesh-andblood ties between the party members and the masses, and serve the people wholeheartedly.

\section{XI JINPING'S ABUNDANT CONNOTATION OF STRICTLY ADMINISTERING THE PARTY'S THOUGHTS}

The comprehensive and strict governance of the party is rich in content, and the combination of "comprehensive", "strict" and "ruling" and "trinity" reveals the new requirements for the construction of the ruling party. Full coverage of the content, full coverage of the period, and full coverage of the main body, that is, facing all party members and party organizations, covering all areas of party building, this is "comprehensive." To strictly govern the party in an all-round way, we must rely on the entire party, manage the entire party, and govern the entire party. Organizational construction, system construction, ideological construction, work style construction, and anti-corruption and honesty building are the "governing the party." Governing the symptoms and tackling the roots, based on the current and long-term perspective is the goal of "governing the party." Party organizations at all levels, cadres at all levels, and all party members are the targets of "governing the party."

The key to strict and thorough management of the party is to "strictly enforce". Taking the party constitution as the highest standard and strictly administering the party with the strictest discipline and the most serious attitude is called "strictness." "Strictness" is an important guarantee for doing all the work, and "strictness" is passed through the whole process of party building.

A comprehensive and strict administration of the party must be aimed at "ruling". From the Party Central to the grassroots party branch, we must shoulder the responsibility and assume the corresponding responsibility called "governance." With the courage to cure the bones, the courage of the strong man to break the wrist, the determination to fight the shackles and the chaos of the code, and resolutely carry out the anti-corruption struggle and the building of the party's style and clean government, this is called the "governance" requirement. "Governance" is a process in which there is a destruction and construction in practice. This process includes both the palliative and the root cause; it not only forms the situation, restrains the "disease", but also eradicates the roots and soil of the disease.[5]

In the report of the 19th National Congress of the Communist Party of China, General Secretary Xi Jinping emphasized that the party's political construction should be placed in the first place. This is a major innovation of the party Central with the comrades of Comrade Xi Jinping as the core of the party's construction. To firmly promote the comprehensive and strict administration of the Party and make the Party's construction more robust, we must take the Party's political construction as the leading factor, ensure that the Party always takes charge of the overall situation, coordinate all parties, It is of great significance and far-reaching to take the overall situation and coordinate the parties and lead the whole party and the whole army and the people of all nationalities in the country to strive to take the long march of the new era. The Communist Party of China has always been an important force in promoting the development and progress of China's history. We must strengthen party governance, If we want to govern our party and our country, we must ensure the unity of the party. We must resolutely safeguard the authority of the party Central.

\section{XI JINPING'S CONTEMPORARY VALUE OF STRICTLY ADMINISTERING THE PARTY'S THOUGHT}

\section{A. Enriching and developing the Marxist Party Construction Theory}

Strictly administering the party is the core of Marxist party building theory, and it also runs through the development of Marxist parties. On the basis of this, General Secretary Xi Jinping put forward the principle of "ruling the party in an allround way," which is in line with the strict administration of the Party and keeps pace with the times. It is a great breakthrough in Marxist theory of Party building to inherit and enrich the thought of strictly administering the Party. First of all, the strict management of the party's thinking is the essential requirement of the Marxist party and has always been the proletarian revolution. Secondly, strictly administering party ideology is a valuable experience in the construction of Marxist political parties and an important advantage of the party. Finally, the thought of strictly administering the Party in an allround way inherits the fundamental requirement of strictly administering the Party, summarizes the valuable experience of strictly administering the Party scientifically, inherits and carries forward the fine tradition of strictly administering the Party, and further enriches and develops the Marxist theory of Party building.

That the comprehensive and strict management of the party's thinking strictly manage the party's thinking and ensure that party members and cadres correctly exercise the powers conferred by the people, and put power into the cage of the system to form a new normal state of institutional control. We will resolutely correct the "four winds" and constantly improve the ideological style, life style, leadership style, and work style of party members and cadres. This shows that the inheritance, continuation and development of the party's ideology have revealed to the world that at the new starting point, our party's determination and confidence in governing the party and managing the new pattern of the party will help boost morale. General Secretary Xi Jinping used the developed Marxist theory to guide the construction of the Communist Party of China and continuously enrich the development of Marxist party building.

For the Chinese Communist Party, the flesh-and-blood ties with the people are the historical experience of our party's success. To strictly manage the party in an all-round way is to dare to take responsibility and achieve full coverage and full 
coverage of the content. To strictly manage the party in an allround way is to embody strict discipline in daily management and supervision so that the majority of party members can truly observe discipline.

\section{B. Improving the scientific level of party building}

Comprehensively administering the party strictly has improved the level of party's ideological building. The cornerstone of party building is ideological construction, which exists in other party building. To strengthen the building of ideology, the first is to study Marxist theory, and the second is to maintain the purity and advancement of the party. Party members and cadres should put the strengthening of ideological construction in a prominent position, implement the spirit of the 19th Party Congress, and consciously arm the mind with the theoretical system of socialism with Chinese characteristics.

Comprehensively administering the party strictly has improved the level of party organization. The key content of the party's construction is organizational construction, especially the building of party cadres. Comprehensively administering the party strictly has broadened the scope of selecting cadres, increased the efforts to promote cadres, and increased the transparency of the selection and employment. Facing the current economic, political and cultural situation in the country, and trying to improve our overall strength and firmly grasp the right to culture, values and ideological discourse power, our party must strengthen the party's organizational level, thereby enhancing the party's ability to govern and enhancing its ability to withstand various risks.

Comprehensively administering the party strictly has improved the level of the party's work style. A major task of the party's construction is to strengthen the party's work style, maintain the ideals and convictions of the Communists, improve the party's leadership and governance, and broaden the political vision of party members. It is inseparable from strengthening the party's style of work, at the same time, the construction of style has effectively curbed the unhealthy trend of mediocrity, laziness and arrogance.

Comprehensively administering the party strictly has enhanced the party's anti-corruption level. The success or failure of the party and the country depends on the party's anticorruption construction. It is of great significance to maintaining the party's prosperity, the party members' integrity, the strength of party members, and the enhancement of the party's combat effectiveness and creativity. Our party has intensified the investigation and handling of violations of disciplines and illegal cases, and effectively ensured the strict implementation of the combination of powers and responsibilities, supervision of powers, accountability for dereliction of duty, and accountability for violations. The responsibility for building the party's style and building a clean government is strictly implemented on everyone's body, and the system of punishing corruption and preventing corruption has been comprehensively promoted, so that cadres are clean and self-sufficient, the government is clean, and the politics is clean.
Comprehensively administering the party strictly has improved the level of the party's system building. The fundamental construction of the party is system construction, and the foundation of the party's prosperity is institutional construction. Adhering to the strict management of the Party, we must focus on solving the problems of the Party's system construction, and truly rely on the system to manage power, affairs, Party members and cadres and the people. We should regard the system construction as an important content of the party construction and the system governance as an important realistic grasp to strengthen and perfect the party construction work.

On the whole, we have comprehensively and rigorously managed the party's thinking to improve the scientific level of party building, and have strengthened and improved the party's ideology from many fields. The majority of party members and cadres must resolute the ideals and beliefs of MarxismLeninism and establish a correct world outlook and life, Views, values.

\section{Providing ideological protection for the goal of "Two Centenary Goals"}

Since the 18th National Congress of the Communist Party of China, the Party Central with General Secretary Xi Jinping as the core has inherited the outstanding theoretical achievements of the former leadership collectives, shouldered the heavy responsibility of history, and led the party and the people throughout the country to achieve the goal of "two hundred years". On the 100th anniversary of the founding of the Party, China will achieve the goal of building a well-off society in an all-round way. On the 100th anniversary of the founding of the People's Republic, China will strive to build a prosperous, democratic, civilized and harmonious socialist modernization country.

General Secretary Xi Jinping stressed: "Now, we are closer to the goal of the great rejuvenation of the Chinese nation than at any time in history, and have more confidence and ability to achieve this goal than at any time in history."[6] To achieve the goal of "two one hundred years", the key is to adhere to the principle of strict and strict administration of the party. In his series of important speeches, General Secretary Xi Jinping's thought of ruling the Party strictly in an all-round way, combined with his own national conditions, has further enriched and developed the theoretical system of socialism with Chinese characteristics. It is the action program of ruling the country and governing the government of our party under the present historical conditions, an important ideological weapon for us to rally our strength and overcome difficulties, also is the action guide to achieve the goal of "two one hundred years". We must have a lofty sense of mission and sense of social responsibility, maintain the party's advanced nature, strengthen our ideals and convictions, earnestly study and implement the series of important speeches that strictly govern the party and adhere to the spirit of the 19th Party Congress and General Secretary Xi Jinping. Under the leadership of the Party, we will comprehensively and strictly manage the new requirements of the party and strictly regulate the political life within the party. 
The comprehensive and strict management of the party's thinking is a party building theory with distinctive characteristics formed under the background of socialist modernization construction and comprehensive deepening reform. It inherits the essence of the thought of ruling the Party strictly and enriches and develops the thought of ruling the Party strictly. It is the latest achievement of the development of the thought of ruling the Party strictly in China and the theoretical basis for ensuring the party's goal of achieving the goal of "two one hundred years".

\section{CONCLUSION}

Xi Jinping's comprehensive and strict management of the party's thinking is the latest achievement in the development of the ideological and theoretical era of party building with Chinese characteristics since the 18th National Congress. In the face of the profound changes in the current domestic and international situation, General Secretary Xi Jinping pointed out the direction of the development of the Communist Party of China in the new era, and pioneered the idea of comprehensively and strictly administering the party with its distinctive characteristics, and answered the question of what kind of party to build and how to build the party under the new era. " Xi Jinping has provided a strong guarantee for the comprehensive management of the party's ideology in order to realize the socialist modernization with Chinese characteristics.

We must grasp the new direction and new methods of party building in the new and new situations, strive to explore the historical laws of the party's development to the present, and constantly enrich Xi Jinping's theoretical system of comprehensively and strictly administering the party's thinking. This is the core issue of China's socialist modernization drive and the key issue for the CPC to improve its own construction.

\section{REFERENCES}

[1] "Xi Jinping talks about governing the country" (Volume II) [M]. Beijing: Foreign Languages Press, 2017.

[2] Xi Jinping. Decisive victory to build a well-off society in an all-round way to win the great victory of socialism with Chinese characteristics in the new era--Report on the 19th National Congress of the Communist Party of China [N]. People's Daily, 2017.

[3] He Xihui. Strategic Thinking on the Unswervingly Advancing the Strictly Administering the Party in a New Era[J].Journal of Hunan Administration College,2018(01).

[4] Di Chengguang. The Scientific System of Xi Jinping's Socialist Thought with Chinese Characteristics in the New Era[J].Journal of China Jinggangshan Cadre College,2018.

[5] Li Chenglin. The rich connotation and significance of General Secretary Xi Jinping's comprehensive management of the party's thoughts [J]. Century Bridge, 2016.

[6] Ren Guixiang. Promoting and Deepening the Study of Party History with Xi Jinping's Exposition on Party History[J].Mao Zedong Research, 2015 . 